\title{
Foreword and Acknowledgements
}

This book is the outcome of a project on 'The Amount and the Effects of Money Laundering' for the Dutch Ministry of Finance, completed in February 2006 by the Utrecht School of Economics, with the support of scholars of the Australian National University in Canberra. The project participants came from five countries and four disciplines and included in alphabetic order Madalina Busuioc, Joras Ferwerda, Wouter de Kruijf, Greg Rawlings, Melissa Siegel, Brigitte Unger and Kristen Wokke. They have all participated in the project with great enthusiasm, diligence and energy. We thank Madalina Busuioc from Romania, for her knowledge of law and wonderful writing style; Joras Ferwerda from the Netherlands, who dealt with the 44,000 entries of the 220 by 220 matrices and who would not give up until he had found an answer to his research question; Wouter de Kruijf from the Netherlands, who kept control over the research output and organized everything so that the different parts of the book fitted together; Melissa Siegel, a social scientist from the US, who pioneered in unpacking the Walker model for money laundering and who had to collect, organize and deal with a huge amount of new data; Kristen Wokke, a Dutch student who wrote his bachelors thesis on the organization of money laundering policies. Greg Rawlings, an anthropologist from the Australian National University, was the consultant of this project. I, Brigitte Unger, an economist from Austria and the Utrecht School of Economics, was the project leader. Marissa van der Valk and Andrea Naylor gave administrative support. Joost Simons and his wife corrected some of the English. Titia Kloos, Willemien Vreekamp and Frans van Eck did the lay out. I thank this young and sparkling project research team, without whose preceding work, help, and support this book would not have been possible.

Many other people have helped as well. Thanks to all of them. In particular I want to mention Eric van Andel, Frank van Erp, Ben Geurts, Bernhard ter Haar, Erich Hille, Edward Kleemans, Oberinspektor J. Mahr, Piet van Reenen, Helene Schuberth, Marret Smekens, Brigitte Slot, Eva Stohanzl, and Pieter Verrest, who accompanied the project as it progressed. Furthermore, I extend my appreciation to the Dutch Central Bank (De Nederlandse Bank), The Dutch Ministry of Finance, and the Dutch Banking Association NVB.

Thanks also to the colleagues of Utrecht School of Economics, in particular to Rob Alessie, Ian Peter Engelen, Gerrit Faber, Filipa Figueira, Peter de Gijsel, Jaap Bos, Bas van Groezen, Loek Groot, Harry Garretsen, Hannah Kiiver, 
Clemens Kool, Thijs Knaap and Ian Reijnders. Donato Masciandaro from Bocconi University Milano, Italy, and Raffaella Barone from the University of Lecce, Italy, also gave useful hints and comments.

I also want to mention Frans van Waarden from University College of Utrecht University, who alternated in reading parts of the manuscript and in cheering up the author.

A very special thanks goes to Greg Rawlings whom I met at the Regulatory Institutions Network (RegNet) in Australia. When he showed me his beautiful $\mathrm{PhD}$ on money laundering in Vanuatu, I really somehow regretted that economists when compared to anthropologists, have such a dry and limited use of language. He not only helped to shape the project from the very beginning, but also contributed substantially to the introduction of this book. It was he who analysed recent spectacular money laundering cases of Austrian and Dutch banks, it was he who first mentioned the Australian 'Walker' model to me on which the money laundering estimates in this book are based, it was he who introduced me to new data sets and literature. Greg always gave very valuable insights and comments and was very pleasant company. Thank you Greg.

Thanks to John and Valerie Braithwaite at the Regulatory Institutions Network (RegNet) at the Australian National University, and to all the colleagues there, who helped to design the original project draft.

While the research report for the ministry focused on the Netherlands solely, this book tries to incorporate a comparative perspective, by also bringing in money laundering cases from Australia and other countries. Australia is interesting because it is of about the same economic size as the Netherlands. It has a very special location because it is surrounded by a ring of islands of unrest, crime and money laundering, and therefore is an attractive transit country for launderers. Nauru, Vanuatu, Solomon Islands are some of these islands, just to name a few.

The findings of this project received widespread attention in the Dutch media. I am grateful to the Dutch journalists, whose expertise and professionalism allowed a serious public debate. I hope that this book will contribute to enhance the debate between different academic disciplines. 